\author{
SPOLECZNO-WARTOŚCIUJĄCY (NORMATYWNY) \\ A DESKRYPTYWNY CHARAKTER STRONY PODMIOTOWEJ \\ CZYNU ZABRONIONEGO. KOMPLEKSOWE A (CZYSTO) \\ NORMATYWNE UJECCIE WINY (NA PRZYKŁADZIE REGULACJI \\ UROJENIA ZNAMIENIA KONTRATYPU I ZNOWELIZOWANEGO \\ ART. 28 PAR. 1 KK Z 1997 R.)
}

\begin{abstract}
Streszczenie
Tematem artykułu jest sporna w nauce prawa karnego problematyka wzajemnej relacji między istotą czynu zabronionego (niem. Tatbestand) a pozostałymi elementami struktury przestępstwa, tj. bezprawnością czynu oraz winą. Autor szczególną uwagę poświęca zagadnieniu charakteru relacji między stroną podmiotową czynu zabronionego i winą. Ma to związek z wysuwaną w nauce polskiej tezą o konieczności radykalnej separacji tych płaszczyzn, która jest realizowana w przepisach polskiego kodeksu karnego z 1997 roku. Charakterystyczne dla takiego stanowiska są regulacje, których przedmiotem jest błąd co do znamienia sytuacji wyłączającej bezprawność czynu (art. 29) oraz błąd co okoliczności stanowiącej znamię typu (art. $28 \S 1 \mathrm{w}$ brzmieniu nadanym nowelizacją z 20 lutego 2015 r.). U podstaw tych regulacji leży założenie, że znamiona podmiotowe (umyślność i nieumyślność) należą wprawdzie do zespołu znamion typu czynu zabronionego, jednakże nie mają żadnego konstytutywnego znaczenia zarówno przy ustalaniu bezprawności czynu, jak i winy sprawcy. Umyślność i nieumyślność są ostro oddzielone od winy (rozumianej „czysto normatywnie”). W takim ujęciu zespół znamion typu czynu zabronionego (istota czynu) ma charakter deskryptywny i jest wolny

* dr hab. Zbigniew Jędrzejewski prof. UW, Wydział Prawa i Administracji Uniwersytetu Warszawskiego, adres e-mail: z.jedrzejewski@wpia.uw.edu.pl
\end{abstract}


od jakiegokolwiek wartościowania. Stanowisko takie prezentował w nauce niemieckiej twórca „finalizmu” H. Welzel, a w nauce polskiej A. Zoll. Autor artykułu przeprowadza analizę poglądów H. Welzla po jego „ontologicznym zwrocie” w szóstej dekadzie XX wieku. Denormatywizacja pojęcia m.in. umyślności na płaszczyźnie znamion typu czynu zabronionego, jego oddzielenie od każdego kontekstu wartościującego doprowadziło finalistów do przyjęcia tzw. ścisłej teorii winy (die strenge Schuldtheorie). Podobnie rzecz przedstawia się na gruncie systematyki przestępstwa akceptowanej w ośrodku krakowskim (A. Zoll). Urojenie znamienia okoliczności wyłączającej bezprawność nie wyłącza bezprawia czynu umyślnego i rozstrzygane jest wyłącznie na płaszczyźnie winy (art. 29 polskiego kodeksu karnego). Wyrazem poglądu o konieczności denormatywizacji znamion podmiotowych typu jest również nowe brzmienie art. $28 \S 1$.

Autor opracowania prezentuje stanowisko odmienne, opowiadając się za społeczno-wartościującym (normatywnym) ujęciem istoty czynu i umyślności (zamiaru). Oznacza to, że przy określaniu przedmiotu zamiaru (świadomości sprawcy) są lub mogą być istotne nie tylko „okoliczności faktyczne” będące podstawą znamion typu, ale również ich społeczny (normatywny) kontekst i znaczenie, świadomość społecznej szkodliwości), a być może nawet ocena prawna czynu. Pominięcie tego całego kontekstu (umyślność ujęta „naturalistycznie”) prowadzi zaś do tzw. ścisłej teorii winy. Zdaniem Autora, trafna jest koncepcja całkowitego wyłączenia bezprawia umyślnego: w wyniku urojenia znamienia kontratypu sprawca chce obiektywnie czegoś zgodnego z prawem. Jednocześnie umyślność musi znaleźć swoje miejsce (również) na płaszczyźnie winy (kompleksowa, psychologiczno-normatywna teoria winy). Realizacja znamion typu niesie ze sobą zarówno ujemną ocenę w sferze bezprawia (bezprawności), jak i winy. Na obydwu płaszczyznach pełni ona funkcję „wskaźnikową”, a więc typizacja czynu obejmuje również elementy zawinienia. Zdaniem Autora, zamiar bezpośredni należy lokować zarówno w bezprawiu, jak i winie. Kompleksowy, mieszany charakter można również wykazać w przypadku tzw. zamiaru ewentualnego oraz nieumyślności. Dlatego Autor krytycznie ocenia postulaty rezygnacji z kompleksowych konstrukcji lekkomyślności i niedbalstwa oraz wspomnianą wyżej nowelizację art. $28 \S 1$ kodeksu karnego. Jego zdaniem, swego rodzaju domniemanie winy umyślnej może wynikać z wartościującego charakteru umyślności (funkcja w obszarze winy). Konsekwentna denormatywizacja pojęcia nieumyślności (dawnej „lekkomyślność”, „niedbalstwo”) doprowadziła w nauce polskiej do konstatacji, że strona podmiotowa „nieumyślności” to po prostu „brak zamiaru". Nowe brzmienie art. 28 § 1 kodeksu karnego wraz z określonym otoczeniem normatywnym i jego wykładnią (negatywne sformułowania art. 1 § 3 i 28 § 1, obiektywistyczna interpretacja art. 9\$2) prowadzi do niedającego się zaakceptować na gruncie prawa karnego demokratycznego państwa prawnego rezultatu: przyjęcia domniemania winy nieumyślnej na podstawie realizacji li tylko znamion przedmiotowych czynu zabronionego. Potrzeba pozytywnego ustalania możliwości przewidzenia sprawcy na 
podstawie konkretno-indywidualnie (subiektywnie) interpretowanej przesłanki art. $9 \S$ 2 kodeksu karnego (,mógł przewidzieć”) wynika z braku wskaźnikowej funkcji nieświadomej nieumyślności, realizacja znamion takiego typu nie niesie ze sobą ujemnie ocenianej decyzji sprawcy.

Słowa kluczowe: istota czynu (niem. Tatbestand), znamiona typu czynu zabronionego, bezprawność, wina, finalizm, H. Welzel, błąd co okoliczności stanowiącej znamię typu, błąd co do okoliczności stanowiącej znamię sytuacji wyłączającej bezprawność, czysto normatywna teoria winy, tzw. teoria zamiaru (niem. Vorsatztheorie), tzw. ścisła teoria winy (niem. die strenge Schuldtheorie), kompleksowa, psychologiczno-normatywna teoria winy, teoria negatywnych znamion czynu zabronionego, finalność, zamiar ewentualny, nieumyślność, niedbalstwo, funkcja wskaźnikowa realizacji znamion typu, funkcja wskaźnikowa realizacji znamion strony podmiotowej, art. 28 par. 1 kodeksu karnego, art. 29 kodeksu karnego

Nowelą z 20 lutego 2015 roku nadano nowe brzmienie art. 28 § 1 KK z 1997 roku: „Nie popełnia przestępstwa, kto pozostaje w usprawiedliwionym błędzie co do okoliczności stanowiącej znamię czynu zabronionego"1. Na temat tej nowelizacji wypowiedziałem się już m.in. w publikacji na łamach „Studia Iuridica”2. Zmiana brzmienia art. $28 \S 1 \mathrm{KK}$ jest kolejnym elementem ustawowego umocowania koncepcji przestępstwa sformułowanej w otoczeniu tzw. szkoły krakowskiej (A. Zoll), opartej na postulacie ostrego rozdzielania przedmiotu oceny od samej oceny, tj. w tym przypadku przede wszystkim radykalnej separacji strony podmiotowej czynu zabronionego od winy. Według tego ujęcia, znamiona podmiotowe (umyślność i nieumyślność) należą wprawdzie do zespołu znamion typu czynu zabronionego (tzw. czyn karalny), jednakże nie mają żadnego konstytutywnego znaczenia przy ustalaniu bezprawności czynu (wyłącznie przedmiotowe warunki przekroczenia normy sankcjonowanej), są jedynie znamionami karalności (hipotezy normy sankcjonującej). Umyślność i nieumyślność są ostro oddzielone od winy, która rozumiana jest „czysto normatywnie”, tak więc nie

1 Pierwotne brzmienie tego przepisu: „Nie popełnia umyślnie czynu zabronionego, kto pozostaje w błędzie co do okoliczności stanowiącej jego znamię".

2 Zob. Z. Jędrzejewski, Artykut $28 \$ 1$ KK po nowelizacji z dnia 20 lutego 2015 r. Uwagi na temat konieczności oddzielania strony podmiotowej czynu zabronionego od winy, „Studia Iuridica”, 2016, t. 65, s. 25 i n.; idem, Strona podmiotowa $i$ wina, przedmiot oceny i ocena a tzw. ścista teoria winy, w: Prawo wobec problemów społecznych. Ksiega Jubileuszowa Profesor Eleonory Zielińskiej, red. B. Namysłowska-Gabrysiak, K. Syroka-Marczewska, A. Walczak-Żochowska, Warszawa 2016, s. 143 i n.; idem, Struktura przestęstwa. §5 Bezprawność, w: System Prawa Karnego, t. 3, Nauka o przestępstwie. Zasady odpowiedzialności, red. R. Dębski, Warszawa 2017, wyd. II, s. 367 i n. 
mają one znaczenia również przy ustalaniu winy. Formalne założenie metodologiczne radykalnej separacji przedmiotu oceny (zespołu znamion typu czynu zabronionego) od samej oceny (oceny bezprawności i zarzutu zawinienia) musi prowadzić do denormatywizacji, neutralności ocennej samego obiektu. „Istota czynu zabronionego" powinna być więc wtedy właściwie wolna od jakiegokolwiek wartościowania, zarówno w aspekcie bezprawności czynu, jak i jego zawinienia. Takie ujęcie Tatbestand prezentował wcześniej m.in. H. Welzel.

Konsekwencje tego stanowiska można zidentyfikować właśnie na podstawie założeń metodologicznych i systematyki czynu przestępnego finalizmu. Błyskotliwą, krytyczną analizę stanowiska finalistycznego przeprowadził już w 1962 roku znakomity niemiecki karnista C. Roxin w rozprawie pt. Zur Kritik der finalen Handlungslehre ${ }^{3}$. Finaliści lokowali znamiona podmiotowe (finalność = zamiar) w typie czynu zabronionego, konkretnie w typie bezprawia czynu, a winę ujmowali czysto normatywnie. Moim zdaniem, tzw. ujemność (bezprawie) zamiaru (Handlungsunwert), ,wola urzeczywistnienia skutku” H. Welzla, zawierała, przynajmniej w niektórych konstrukcjach, również elementy określające sytuację motywacyjną sprawcy przy podejmowaniu decyzji popełnienia czynu zabronionego (elementy winy), np. w przypadku bezprawia usiłowania nieudolnego (jedyną podstawą ujemności było tu tzw. bezprawie intencji - Intentionsunrecht). W ramach finalizmu w wersji welzlowskiej aksjomatem systematyki przestępstwa było finalne, ontologiczne ujęcie czynu. Prowadziło to również do: 1) denormatywizacji pojęcia zamiaru na płaszczyźnie znamion typu czynu zabronionego, jego „wypreparowania” i oddzielenia od każdego kontekstu wartościującego, w konsekwencji do przenoszenia wszelkich ocen związanych z procesem podejmowania decyzji czynu zabronionego na płaszczyznę winy (np. tzw. ścisła teoria winy w wypadku nieświadomości bezprawności czy urojenia znamienia kontratypu); 2) denormatywizacji całej istoty czynu (Tatbestand) w relacji do bezprawności, np. przenoszenia $\mathrm{z}$ istoty czynu do bezprawności wszelkich tzw. znamion normatywnych istoty czynu; denormatywizując istotę czynu, w pewnym okresie H. Welzel uznawał tzw. zachowania społecznie adekwatne jako zachowania kontratypowe.

Podobnie rzecz przedstawia się na gruncie systematyki akceptowanej w ośrodku krakowskim. W zakresie winy najbardziej jaskrawym efektem denormatywizacji znamion podmiotowych typu jest negatywne określenie nieumyśl-

3 Zob. C. Roxin, Zur Kritik der finalen Handlungslehre, „Zeitschrift für die gesamte Strafrechtswissenschaft" 1962, Bd. 74, s. 515 i n. 
ności jako po prostu „brak umyślności” oraz opowiedzenie się expressis verbis za przyjęciem domniemania winy jedynie na podstawie realizacji przez sprawcę przedmiotowych znamion typu (czyn nieumyślny).

Charakterystyczne konsekwencje stanowiska H. Welzla wystąpiły w postaci tzw. otwartych zespołów znamion (offene Tatbestände) oraz tzw. znamion obowiązku prawnego (Rechtspflichtmerkmale). Określał on Tatbestand jako „die im Strafrecht mit besonderer Sorgfalt vorzunehmende sachliche, gegenständliche Beschreibung des verbotenen Verhaltens"4. Porządek prawny musi podać „materię” swoich zakazów (Verbotsmaterie). Ta „materia zakazu” zawiera rzeczowy, przedmiotowy opis, „wzór zachowania” zakazanego. H. Welzel lokował zamiar w istocie czynu, tak więc musiał go również zaliczać do treści (materii) normy (zakresu normy sankcjonowanej). W jego ujęciu, każdy czyn realizujący znamiona istoty czynu przekracza normę, ale nie zawsze jest także bezprawny (wypowiedzi zezwalające). Bezprawność ma charakter jednolity, jest sprzecznością urzeczywistnienia istoty czynu z porządkiem prawnym jako całością (a nie jedynie z pojedynczą normą). Zgodność zachowania z istotą czynu (,znamienność” - Tatbestandsmäßigkeit) i tym samym jego sprzeczność z pojedynczą normą (Normwidrigkeit) jest tylko poszlaką, wskazaniem (ein Indiz) na bezprawność, nie jest więc z tą bezprawnością identyczna. Wypowiedzi zezwalające (okoliczności usprawiedliwiające - Rechtfertigungsgründe) wyłączają bezprawność zachowania, a nie jego zgodność z istotą czynu - materią zakazu . Wraz z pełną realizacją znamion istoty czynu zachowanie jest więc bezprawne, o ile nie znajduje zastosowania żadne zezwolenie (postępowanie negatywne przy ustalaniu bezprawności). Są to tzw. zamknięte istoty czynu (geschlossene Tatbestände). W tych wypadkach zakres uzasadniających bezprawie znamion jest pozbawiony luk. Jednak istnieją również istoty czynu, przy których ustawa opisuje tylko część znamion, natomiast pozostałą część pozostawia do uzupełnienia sędziemu, podając mu tylko kryteria, według których należy takiego dopełnienia dokonać. Są to „wymagające uzupełnienia”, „otwarte” istoty czynu (materia zakazu nie została wyczerpująco opisana za pomocą znamion rzeczowo-przedmiotowych). Realizacja znamion takiej istoty czynu nie wskazuje (nicht indiziert)

4 Zob. H. Welzel, Das Deutsche Strafrecht. Eine systematische Darstellung, 11 Aufl. Berlin 1969, s.49 i n. Szerzej na ten temat zob. Z. Jędrzejewski, Bezprawność jako element przestępności czynu. Studium na temat struktury przestępstwa, Warszawa 2009, s. 229-245.

5 Zob. H. Welzel, Das Deutsche Strafrecht, 11 Aufl, s. 81 i n. Na ten temat Z. Jędrzejewski, Bezprawność..., s. 231. 
na bezprawność. Sędzia po stwierdzeniu realizacji znamion otwartej istoty czynu musi ustalić pozytywnie bezprawność przez wykazanie tzw. znamion obowiązku prawnego.

Jednak wcześniejsze, przedwojenne ujęcie istoty czynu i zamiaru (finalności) H. Welzla miało charakter wyraźnie normatywizujący ${ }^{6}$. „Zwrotu ontologicznego" dokonał zaś w szóstej dekadzie ubiegłego wieku. Jeszcze w pierwszym wydaniu swojego podręcznika prawa karnego z 1947 roku ujmował istotę czynu wartościująco jako typizację karnego bezprawia, twierdził, że zachowanie społecznie adekwatne nie realizuje istoty czynu (nie przekracza normy), bowiem w innym wypadku istota czynu przestałaby być typizacją bezprawia ${ }^{7}$. Treść używanych przy opisie czynu zabronionego pojęć, np. „zabijać czy „naruszać”, wynika dopiero z ich funkcji we wspólnocie społecznej, której porządek one naruszają. Jego zdaniem, zasadniczym błędem tradycyjnej nauki było to, że zachowanie opisane w istocie czynu redukowała ona do stosunków naturalistyczno-kauzalnych, a prawno-socjalny świat wartości uwzględniała dopiero na płaszczyźnie bezprawności. Nie może więc dziwić, że Welzel w swoich przedwojennych publikacjach nie uznawał jako zgodnego z istotą czynu np. zabicia człowieka na wojennym polu walki ${ }^{8}$. Można zaryzykować tezę, że zbliżał się on wtedy do teorii negatywnych znamion czynu zabronionego (!), a przecież znany jest z późniejszej długotrwałej, nieustępliwej opozycji wobec tej teoriii ${ }^{9}$. Zamiar i finalność, jako znamiona istoty czynu, w jego wczesnym stanowisku były również pojęciami relatywnymi i zależnymi od zmiennej rzeczywistości społecznej: konkretny czyn finalny musi zawierać oceny i wyrażać prawno-socjalne treści znaczeniowe, miał być społecznie znaczącym fenomenem jako czyn w społecznej przestrzeni życiowej. „Społeczna adekwatność” zachowania w ujęciu H. Welzla miała charakter zdecydowanie normatywno-wartościujący ${ }^{10}$. W konsekwencji społecznie adekwatne zachowanie nie realizowało znamion istoty czynu, nie przekraczało normy (sankcjonowanej).

6 Podstawowa praca z tego okresu zob. H. Welzel, Studien zum System des Strafrechts, „Zeitschrift für die gesamte Strafrechtswissenschaft” 1938, Bd. 58, s. 491 i n. Szerzej na ten temat Z. Jędrzejewski, Bezprawność..., s. 524 i n.

7 H. Welzel, Das Deutsche Strafrecht in seinen Grundzügen, Berlin 1947, 1 Aufl., s. 34 i n., 37, 46; zob. C. Roxin, Offene Tatbestände und Rechtspflichtmerkmale, Hamburg 1959, s. 45-46. Na ten temat zob. Z. Jędrzejewski, Bezprawność..., s. 236 i n.

8 H. Welzel, Studien..., s. 529. Zob. Z. Jędrzejewski, Bezprawność..., s. 237.

9 Zob. Z. Jędrzejewski, Bezprawność..., s. 237-238.

10 Zob. ibidem, s. 236 i n., 239 i n., 242 i n. 
Jeżeli czyn finalny zostanie „,zanurzony” w kontekście społecznym, to przy konstrukcji zamiaru trzeba uwzględnić całą sytuację, w której czyn jest realizowany, a nie wyłącznie samą wolę naruszenia dobra prawnego. Podkreślanie tego społeczno-normatywnego kontekstu umyślnego bezprawia prowadzi do tego, że przy konstrukcji przedmiotu zamiaru (przedmiotu świadomości sprawcy) istotne są lub mogą być nie tylko „okoliczności faktyczne” będące podstawą znamion typu, ale również ich społeczny sens i znaczenie, „kontekst kontratypowy”, całościowa ocena społeczna (świadomość społecznej szkodliwości), a być może nawet ocena prawna ${ }^{11}$. Każdy normatywizm na poziomie istoty czynu i zamiaru, który zaciera granicę między przedmiotem oceny i samą oceną, stanowi zagrożenie dla „teorii winy”, zwłaszcza w przypadku urojenia znamienia kontratypu. Normatywne ujęcie istoty czynu i umyślności (zamiaru) prowadzi nieuchronnie do konstatacji, że urojenie znamienia kontratypu wyłącza ujemność umyślności, a jednocześnie umyślność musi znaleźć swoje miejsce (również) na płaszczyźnie winy ${ }^{12}$. W przypadku urojenia np. istnienia bezprawnego zamachu sprawca chce naruszyć dobro właśnie w takim (wyobrażonym) kontekście sytuacyjnym, chce ostatecznie (oceniając obiektywnie przedmiot chcenia) czegoś zgodnego z prawem, bez względu na to, czy ewentualnie uroi sobie również legalność swojego zachowania (wyłączenie umyślnego komponentu bezprawia). Jeżeli zaś cały ten (wartościujący) kontekst pominiemy, ujmując umyślność niejako „naturalistycznie", otwiera się droga prowadząca do poglądu o potrzebie ostrego rozdzielania znamion bezbarwnego normatywnie typu czynu zabronionego od znamion kontratypu, którego radykalną konsekwencją może być tzw. ścisła teoria winy (die strenge Schuldtheorie).

Późniejsze stanowisko H. Welzla odnośnie do charakteru pojęcia czynu celowego oraz istoty czynu uległo zmianie w kierunku skrajnej ontologizacji i denormatywizacji ${ }^{13}$. Finalny czyn (zamiar) stawał się ,wieczną”, ,ponadhistoryczną” strukturą rzeczowo-logiczną, ontologicznym, niezmiennym aksjomatem całego systemu. Welzel posługiwał się wtedy wyłącznie metodologią analityczną ${ }^{14}$, w rezultacie relację między istotą czynu i bezprawnością ujmował bardziej formalno-logicznie

11 Zob. Z. Jędrzejewski, Strona podmiotowa..., s. 146.

12 Zob. ibidem, s. 146.

13 Zob. np. H. Welzel, Aktuelle Strafrechtsprobleme im Rahmen der finalen Handlunglehre, Karlsruhe 1953, s. 5. Szerzej zob. Z. Jędrzejewski, Bezprawnośćc.., s. 240 i n., 527.

14 „Wczesny” Welzel krytykował analityczną metodologię naturalizmu i pozytywizmu, preferując metodę „całościową” (Ganzheits-Denken). Zob. np. H. Welzel, Studien..., s. 530. Na ten temat Z. Jędrzejewski, Bezprawność..., s. 239, 522. 
(normo-logicznie), dokonał skrajnej generalizacji bezprawności, opowiedział się za jej jednolitym rozumieniem w całym porządku prawnym (w publikacjach przedwojennych przyjmował koncepcję „różnych” bezprawności), wreszcie sformułował podstawy tzw. ścisłej teorii winy ${ }^{15}$. Jak trafnie zauważył C. Roxin, welzlowska istota czynu, tak daleko jak to możliwe, musiała zostać odseparowana od realnego, zmiennego historyczno-społecznego świata i zredukowana do pojęciowo-abstrakcyjnej, do tego ścisłej i ponadczasowej „superdeterminacji” procesami kauzalnymi ${ }^{16}$. W zasadzie wolna od wartościowania istota czynu (w tym całkowicie neutralny zamiar) musiała prowadzić do rozwiązania problemu błędu co do bezprawności oraz urojenia znamienia kontratypu na płaszczyźnie normatywnej winy (świadomości bezprawności). Tak zwana ścisła teoria winy odpowiada więc bez wątpienia tendencjom do skrajnej ontologizacji czynu celowego i nie da się pogodzić z wartościującym ujęciem umyślności ${ }^{17}$. Kierowanie procesem kauzalnym przez sprawcę oznacza tu realizację znamion istoty czynu zabronionego, niezależnie od konkretnego (wartościującego) kontekstu czynu. W ramach istoty czynu kontekst ten jest pomijany, a zamiar go nie obejmuje (nie stanowi przedmiotu umyślności). Zgodnie z takim stanowiskiem, na płaszczyźnie realizacji znamion istoty czynu (znamienności), w tym również znamienia umyślności, nie istnieje żadna różnica między nieraz brutalnym zabójstwem a zabiciem człowieka w obronie koniecznej! ${ }^{18}$

Z „nową”, pozbawioną ocen istotą czynu Welzla, korespondowała oczywiście jego koncepcja tzw. otwartych zespołów znamion i znamion obowiązku prawnego (czystych elementów bezprawności) ${ }^{19}$. Jeżeli usuniemy elementy obowiązku prawnego, otwarte zespoły znamion są całkowicie wolne od wartościowania, nie pełnią funkcji wskazywania (indizieren) na bezprawnośćc ${ }^{20}$. Wraz $\mathrm{z}$ denormatywizacją istoty czynu i zamiaru $\mathrm{H}$. Welzel zmienił w systematyce przestępstwa usytuowanie zachowań społecznie adekwatnych ${ }^{21}$. Społeczna ade-

15 Zob. Z. Jędrzejewski, Bezprawność..., s. 239-240.

16 C. Roxin, Zur Kritik..., s. 538. Na ten temat zob. Z. Jędrzejewski, Bezprawność..., s. 240.

17 Zob. C. Roxin, Zur Kritik..., s. 538 i n.

18 Zob. ibidem, s. 539. Na ten temat Z. Jędrzejewski, Bezprawność..., s. 240.

19 Na ten temat zob. Z. Jędrzejewski, Bezprawność..., s. 241 i n.

20 Zob. C. Roxin, Offene Tatbestände..., s. 44-46.

21 Zob. H. Welzel, Das Deutsche Strafrecht, Berlin 1958, 6 Aufl., s.149; 1960, 7 Aufl., s. 76. Swoje stanowisko, że społeczna adekwatność jest okolicznością wyłączającą bezprawność, podtrzymywał do 8. wydania swojego podręcznika (1963). Później ponownie je zmienił: społecznie adekwatne zachowanie nie realizuje istoty czynu. Zob. H. Welzel, Das Deutsche Strafrecht..., 11 Aufl., 1969, s. 55-58. 
kwatność czynu nie wyłączała już realizacji znamion istoty czynu, lecz po prostu stała się okolicznością usprawiedliwiającą czyn (wyłączającą jego bezprawność $)^{22}$. Taki pogląd Welzla jako wynik przyjęcia neutralnej istoty czynu dziwić nie może. Funkcja społecznej adekwatności polegająca na wyłączeniu realizacji istoty czynu (brak przekroczenia normy sankcjonowanej) jest możliwa jedynie wtedy, gdy istotę czynu ujmuje się wartościująco jako typizację bezprawia ${ }^{23}$.

Radykalna denormatywizacja istoty czynu zabronionego prowadzić musi do radykalnego rozgraniczenia zakresu istoty czynu (typu) od zakresu znamion kontratypu. Z kolei przedmiotem „ontologicznego” zamiaru mogą być jedynie znamiona deskryptywne typu (nie obejmuje on znamion ocennych oraz znamion kontratypu). Denormatywizacja strony podmiotowej (umyślności i nieumyślności) sprzyja więc zdecydowanie przyjęciu czysto normatywnej teorii winy, w konsekwencji prowadzi do odrzucenia tzw. teorii zamiaru (Vorsatztheorie).

Jeżeli przyjęlibyśmy tradycyjne pojęcie winy umyślnej, to jej odpowiednikiem może być jedynie sytuacja, w której czyn popełniany jest przez sprawcę umyślnie ze świadomością jego bezprawności. Moim zdaniem, to dokładne przeciwieństwo ujęcia finalistycznego. Vorsatztheorie jest rezultatem wartościującego ujęcia umyślności ( $\mathrm{w}$ sferze intelektualnej wina umyślna = znajomość znamion + świadomość bezprawności czynu). Zwolennik tej teorii, który uzna, że błąd co do (znamion) kontratypu to błąd co do bezprawności (tak jak finaliści), przyjąć musi więc i tutaj wyłączenie winy umyślnej (finaliści: brak wyłączenia umyślności). W wypadku ujęcia finalistycznego różnice między zachowaniami: umyślnym przy świadomości bezprawności a umyślnym bez świadomości bezprawności, choćby w wyniku urojenia znamienia kontratypu, nie mają charakteru jakościowego (identyczne bezprawie), lecz wyłącznie ilościowy, w sferze winy. Pojęcie winy umyślnej ulega tu deprecjacji lub znika. Istnieją tylko czyny umyślne (bezprawie umyślne) popełniane ze świadomością bezprawności bądź bez takiej świadomości.

Dla finalistów Schuldtheorie stanowi „logiczny” wynik ich aksjomatycznie ufundowanego pojęcia przestępstwa (rezultat systemowy), w zasadzie nie jest natomiast środkiem zaradzenia trudnościom w każdorazowym ustalaniu istnienia świadomości bezprawności czynu czy przedmiotem rozważań o zakresie spełniania wymogów umyślnego zawinienia. $Z$ tego zaś ostatniego punktu widzenia

22 Na ten temat Z. Jędrzejewski, Bezprawność..., s. 242-243.

23 Zob. F. Schaffstein, Soziale Adäquanz und Tatbestandslehre, „Zeitschrift für die gesamte Strafrechtswissenschaft" 1960, Bd. 72, s. 373. 
tzw. teoria winy wprowadza domniemanie istnienia (potencjalnej) świadomości bezprawności (por. np. negatywne sformułowanie § 17 niemieckiego StGB i art. 30 polskiego KK z 1997 r.), przy czym na gruncie ujęcia wolnej od wartościowania istoty czynu (w tym umyślności) domniemanie takie nie znajduje żadnego oparcia (deskryptywny, wolny od wartościowania przedmiot umyślności). W wypadku koncepcji wartościującego ujęcia zamiaru wprowadzenie takiego domniemania oznacza wprawdzie obniżenie standardu zawinienia umyślnego czynu, ale istnieją tu przynajmniej podstawy takiego domniemania w przyjmowanym ocennym charakterze znamion czynu zabronionego lub łatwo rozpoznawalnej społecznej ujemności wielu czynów.

O ile zdecydowana większość ustawodawstw i doktryny w przypadku bezpośredniego i pośredniego błędu co do bezprawności (sprawca sądzi, że dane okoliczności porządek prawny uznaje za kontratyp, bądź rozszerza błędnie granice uznanego przez prawo kontratypu) opowiada się za rozwiązaniem Schuldtheorie (lub zbliżonym), problem urojenia znamienia kontratypu nadal pozostaje przedmiotem szczególnie intensywnego sporu. Ograniczone ramy artykułu nie pozwalają oczywiście na przedstawienie wszystkich koncepcji. Najbardziej prominentni finaliści (H. Welzel, A. Kaufmann, W. Niese czy H.J. Hirsch) teorię winy stosowali również w sytuacji urojenia znamienia kontratypu (tzw. ścisła teoria winy). Nie dopuszcza się tu wyjątku: także błąd co do znamienia kontratypu jest błędem co do bezprawności (za urojeniem znamienia idzie przekonanie o legalności zachowania), samo zachowanie pozostającego w błędzie pozostaje bezprawne (bezprawie umyślne). Szczególna regulacja błędu co do znamienia kontratypu jest więc zbędna, całą sprawę powinien załatwić przepis dotyczący błędu co do bezprawności. Powojenna „ontologizacja” czynu celowego doprowadziła H. Welzla do radykalnej koncepcji Leitbildtatbestand, (czysto) normatywnego ujęcia winy oraz tzw. ścisłej teorii winy. Stał się on gorliwym przeciwnikiem teorii negatywnych znamion czynu zabronionego. W ujęciu finalistów (Welzla) funkcją kontratypów było jedynie wyłączanie bezprawności (legalizacja wtórna), czyn przekraczał więc normę, chociaż był („wtórnie”) legalny. Stąd błąd co do znamienia kontratypu był traktowany jako zwykły błąd co do bezprawności. Wszystkie okoliczności czy znamiona „podejrzewane” o charakter wartościujący finaliści przesuwali albo do bezprawności (Rechtspflichtmerkmale czy kontratypy), albo do winy (ujmowanej czysto normatywnie jako zarzut stawiany sprawcy). Uwolnienie bowiem zamiaru (czynu finalnego) od jakiegokolwiek kontekstu wartościującego, w tym również od kontekstu kon- 
tratypowego, prowadzi do wniosku, że zamiar na kontratypy nie może się rozciągać. Przypomnijmy, że we wcześniejszym stanowisku Welzla (druga połowa lat trzydziestych) o bardzo mocnym zabarwieniu normatywnym „uwikłanie” czynu finalnego w kontekst społeczny musiało przy konstrukcji zamiaru prowadzić do uwzględniania całej sytuacji (społecznego kontekstu), w której czyn jest urzeczywistniany. W konsekwencji akcentowanie społecznego, wartościującego kontekstu umyślnego bezprawia (normatywnie ujęty zamiar) prowadzi przy urojeniu kontratypu do wyłączenia umyślnego bezprawia (umyślności) ${ }^{24}$. Welzel przed swoim radykalnym „ontologizującym” zwrotem daleki był od koncepcji błędu co do bezprawności ${ }^{25}$. Urojoną obronę konieczną traktował jako przypadek wyłączenia finalnego panowania nad czynem (finale Tatherrschaft), a więc wyłączenia zamiaru ${ }^{26}$.

Finaliści i zwolennicy ścisłej teorii winy twierdzą często, że po realizacji znamion istoty czynu (Leitbildtatbestand) wyłączenie bezprawności może nastąpić tylko wtedy, gdy istnieją zarówno elementy obiektywne, jak i subiektywne kontratypu. Brak jakiegokolwiek znamienia dekompletuje znamiona kontratypu, wyłączenie jednolitej bezprawności jest wtedy niemożliwe. Częściowe wypełnienie znamion okoliczności wyłączającej bezprawność, czy to w wypadku istnienia jedynie jej strony subiektywnej (urojenie znamienia kontratypu), czy realizacji tylko znamion obiektywnych (nieświadomość sytuacji kontratypowej), nie ma dla bezprawia czynu żadnego znaczenia. Wyłączenie bezprawności następuje tylko wtedy, gdy istnieją wszystkie (przedmiotowe i podmiotowe) znamiona kontratypu (zasada „wszystko albo nic”). Welzlowski formalizm ujęcia bezprawności nie dopuszczał tu w ogóle stopniowania bezprawia (ujemności). Ścisła teoria winy przynosi w każdej sytuacji najbardziej niekorzystne dla sprawcy skutki. W przypadku urojenia znamienia kontratypu odpowiada on za czyn umyślny (przy zawinionym błędzie), w sytuacji nieświadomości istnienia znamion kontratypu za umyślny czyn dokonany ${ }^{27}$.

We współczesnej doktrynie niemieckiej przeważa jednak pogląd odmienny. W przypadku urojenia kontratypu przyjmuje się albo wprost wyłączenie bezprawia umyślnego (winy umyślnej), albo wyłączenie odpowiedzialności za czyn umyślny (z winy umyślnej). W nauce polskiej A. Zoll uznawał błąd co do zna-

24 Zob. C. Roxin, Zur Kritik..., s. 536 i n.

25 Zob. H. Welzel, Studien..., s. 524.

26 Na ten temat Z. Jędrzejewski, Bezprawność..., s. 526.

27 Zob. ibidem, s. 538. 
mienia kontratypu za błąd szczególnego rodzaju, niebędący wprawdzie błędem co do bezprawności, ale prowadzący zawsze do nieświadomości bezprawności ${ }^{28}$. To błędne ostatnie założenie, że urojenie znamienia kontratypu zawsze prowadzi do urojenia legalności czynu, spowodowało, że regulację art. 29 polskiego KK należy uznać za rozwiązanie w ramach Schuldtheorie. Urojenie znamienia kontratypu nie zmienia nic w bezprawiu czynu, a w przypadku zawinienia tego błędu jedynym elementem wpływającym na wymiar kary (jej nadzwyczajne złagodzenie) jest (obniżona) wina sprawcy. Poglądy A. Zolla odnośnie do stosunku między istotą czynu a bezprawnością i winą pokrywają się ze stanowiskiem finalistów, w efekcie odrzuca on zdecydowanie teorię negatywnych znamion czynu zabronionego.

Teoria negatywnych znamion jest przede wszystkim stanowiskiem co do relacji między istotą czynu a zespołem znamion sytuacji wyłączającej bezprawność, można wszakże uznać, że jest wynikiem radykalnej normatywizacji typu czynu zabronionego, poglądu przyjmowanego szczególnie pod wpływem neokantyzmu ${ }^{29}$. Istotę czynu zaczęto ujmować wartościująco i nie separowano od bezprawności. Zwolennicy tej teorii podkreślają, że jeżeli realizacja istoty czynu ma stanowić ratio essendi bezprawności, to musi ona obejmować wszystkie znamiona to bezprawie określające, a nie tylko jakąs ich część, nie dawać „prowizorycznej”, lecz ostateczną ocenę bezprawności zachowania. Będą to więc znamiona zarówno w tradycyjnym znaczeniu tę bezprawność uzasadniające, jak i brak znamion sytuacji ją wyłączających. Zanegowane znamiona kontratypów stają się więc znamionami typu czynu (negatywnymi). Nie trzeba przypominać, że teoria ta zyskała w nauce niemieckiej wielu wybitnych zwolenników, zaś w Polsce przyjęli ją nieliczni (m.in. W. Wolter oraz W. Mącior). Jej reprezentanci posługują się szerokim ujęciem istoty czynu zabronionego (Gesamttatbestand), w której zmieszane są nierozdzielne tak różne kategorie jak przedmiot oceny i sama ocena. Rozróżnienie między błędem co do znamienia typu a błędem co do bezprawności jest niemożliwe. Przy ustalaniu zamiaru świadomość sprawcy powinna obejmować znamiona wraz z właściwą dla nich oceną. Często przy tym neguje się deskryptywny charakter znamion. Znamiona ocenne (normatywne) istoty czynu są nośnikiem ujemnej oceny czynu, a ich rozpoznanie jest bliskie

28 A. Zoll, Okoliczności wytaczające bezprawność czynu, Warszawa 1982, s. 153 i n.

$29 \mathrm{Na}$ temat teorii negatywnych znamion czynu zabronionego szerzej $Z$. Jędrzejewski, Bezprawność..., s. 245 i n., 533 i n.; zob. również idem, Okoliczności wytączające bezprawność. Zagadnienia ogólne, w: System Prawa Karnego, t. 4, Nauka o przestępstwie. Wyłączenie i ograniczenie odpowiedzialności karnej, red. L. Paprzycki, Warszawa 2016, wyd. II, s. 41 i n. 
bądź identyczne ze świadomością bezprawia ${ }^{30}$. Takie ujęcie otwiera drogę do akceptacji teorii zamiaru (Vorsatztheorie). Jeżeli świadomość przy zamiarze ujmować będziemy bardziej w kierunku łączenia jej z jakąś świadomością pewnej ujemności społecznej czynu, szkodliwości czynu czy bezprawia, co doskonale ilustruje konieczność uwzględniania w świadomości sprawcy ocen związanych ze znamionami normatywnymi, to wtedy trudno przyjąć, by przy urojonym znamieniu kontratypu istniał zamiar, skoro sprawca sądzi (błędnie), że działa zgodnie z prawem, a przynajmniej to, co chce zrealizować, nie jest, obiektywnie oceniając, niezgodne z prawem (sprawca chce zabić i sądzi, że działa w obronie koniecznej). Im większa normatywizacja istoty czynu (a to chyba najsilniej podkreśla się w teorii negatywnych znamion), tym mocniejsza normatywizacja przedmiotu świadomości przy zamiarze.

Moim zdaniem zamiar nie może być ujmowany całkowicie neutralnie, tak jak tego chcą finaliści, nie można pozbawić go wszelkich elementów wartościujących. Nie jest możliwa ostra separacja istoty czynu od bezprawności, a także zamiaru nie tylko od świadomości bezprawności, ale w zasadzie od wszelkich ocen, które u finalistów lokowane są w winie. Według nich świadomość sprawcy powinna obejmować znamiona deskryptywne, ponieważ wtedy łatwo wypreparować świadomość bezprawności czy ujemności czynu. Stanowisko odmienne, reprezentowane często przez zwolenników teorii negatywnych znamion, według którego istota czynu i zamiar mają charakter wartościujący (normatywny), przekreśla podstawy (ścisłej) teorii winy ${ }^{31}$. Stanowi ono biegun przeciwny do welzlowskiego pojmowania stosunku istoty czynu do bezprawności (radykalna Leitbildtatbestand, strenge Schuldtheorie) ${ }^{32}$.

Radykalny pogląd o deskryptywnym (wolnym od ocen) charakterze istoty czynu i strony podmiotowej (sfera faktów, przedmiot oceny) należy uznać za całkowicie błędny. Zakłada on, że realizacja znamion typu czynu zabronionego nie niesie ze sobą żadnej ujemnej oceny, zarówno na płaszczyźnie bezprawności, jak i na płaszczyźnie winy. Kwestie bezprawności i winy redukowane są tutaj do (odpowiednio) kontratypów i okoliczności wyłączających winę. Już w tym momencie można postawić pytanie: jaką ujemność miałyby „wyłączać” kontratypy czy okoliczności znoszące zawinienie, jeżeli wypełnienie znamion typu

30 K.H. Kunert, Die normativen Merkmale der strafrechtlichen Tatbestände, Berlin 1958, s. 58. Na ten temat zob. Z. Jędrzejewski, Bezprawność..., s. 259-260.

31 Zob. Z. Jędrzejewski, Bezprawność..., s. 261; idem, Strona podmiotowa..., s. 146.

32 C. Roxin, Offene Tatbestände..., s. 44; zob. Z. Jędrzejewski, Bezprawnośćc.., s. 262. 
nie wiązałoby się z typową, choć „wzruszalną”, oceną bezprawności czynu lub typową, choć „wzruszalną”, oceną jego zawinienia. Dlatego realizacja znamion typu niesie ze sobą zarówno ujemną ocenę w sferze bezprawia (bezprawności), jak i winy ${ }^{33}$. Na obydwu płaszczyznach znamienność czynu pełni funkcję „wskaźnikową". W aspekcie winy, może poza niedbalstwem (nieświadomość realizacji znamion), podstawowe znaczenie ma strona podmiotowa czynu. Warto jednak podkreślić, że finaliści zaliczyli umyślność do istoty określającej bezprawie czynu (a nie winę), w niektórych wariantach skrajnie je subiektywizując. Zamiar stał się samodzielnym elementem bezprawia (Handlungsunrecht), a ujemność skutku (Erfolgsunrecht) w niektórych wariantach finalizmu pozostała elementem niekiedy nawet nieistotnym (co najwyżej, skutek był warunkiem karalności). Ta wyraźna różnica w odniesieniu do innych gałęzi prawa (np. cywilnego) powinna prowadzić do przyjęcia różnych, specyficznych bezprawności, w tym bezprawności karnej. Finaliści wychodzili zawsze z „ontologicznego” aksjomatu czynu celowego, który ustawodawca zastaje i musi go respektować. Pominę krytykę tego stanowiska. Wystarczy przypomnieć tylko, że nie uporali się oni nigdy z wkomponowaniem czynu celowego w strukturę bezprawia czynów nieumyślnych, a całkowitym niepowodzeniem zakończyły się próby zaadaptowania czynu celowego na gruncie prawa cywilnego. W swoich przedwojennych publikacjach Welzel akceptował koncepcję różnych (zorientowanych na czyn oraz zorientowanych skutkowo) bezprawności nawet w obszarze prawa karnego.

Nie podzielam stanowiska, według którego bezprawność czynu jest jednolita w całym porządku prawnym, że nie może być ona prawnokarnym produktem. Nietrafność poglądu, że pojęcia takie, jak bezprawność i wina, są lub powinny być jednolicie pojmowane w każdej gałęzi prawa, np. karnego i cywilnego, jest dla mnie oczywista. Kryterium funkcjonalne ma tu znaczenie decydujące. Pewność obrotu i charakter odpowiedzialności odszkodowawczej, jeżeli jako jej warunek przyjmuje się bezprawność czynu, prowadzi do jej zasadniczo obiektywnego charakteru, nawet pojęcie winy ulega obiektywizacji, a kryterium należytej staranności - generalizacji (nie oznacza to, że $\mathrm{w}$ prawie cywilnym $\mathrm{w}$ ogóle rezygnujemy $\mathrm{z}$ elementów podmiotowych). Prewencja nie odgrywa tu większej roli. Znaczenia funkcji prewencyjnej prawa karnego nie da się natomiast zakwestionować. Rzeczą ciekawą jest przy tym, że nawet teoretycy prawa w swoich rozważaniach kładą szczególny nacisk na funkcję motywacyjną normy. Gdyby spełnić wszystkie postulaty związane

33 Zob. Z. Jędrzejewski, Artykut $28 \S 1$ KK..., s. 35 i n.; idem, Struktura przestępstwa. $\$ 5$ Bezprawność..., s. 368 i n. 
z takim charakterem normy, to na gruncie prawa karnego musielibyśmy włączyć do zakresu (warunków przekroczenia) normy sankcjonowanej (bezprawności) np. wymóg poczytalności, wieku czy rozpoznawalności bezprawności czynu i przyznać rację starej teorii imperatywów, w konsekwencji zrezygnować z rozróżnienia bezprawności i winy. W ramach funkcji motywacyjnej musi wystarczyć włączenie umyślności do zakresu warunków przekroczenia normy sankcjonowanej (karnej).

Nie mam wątpliwości, że typizacja czynu obejmuje również elementy zawinienia. Realizacja przez sprawcę wszystkich - przedmiotowych i podmiotowych - znamion typu czynu zabronionego niesie ze sobą ocenę zachowania w relacji do dobra prawnego (niem. bezprawie - ustalenie bezprawności czynu), a także typową ocenę procesu decyzyjnego sprawcy (wina). W znamionach niektórych typów (najczęściej typów zmodyfikowanych) znajdują się nawet tzw. czyste elementy winy, tj. znamiona określające wyłącznie sytuację motywacyjną lub decyzyjną sprawcy, które nie stanowią refleksu bezprawia (np. znamiona: „w wyniku motywacji zasługującej na szczególne potępienie" - art. $148 \S 2$ pkt $3 \mathrm{KK}$; „pod wpływem silnego wzburzenia usprawiedliwionego okolicznościami” art. 148 § $4 \mathrm{KK}$; ,pod wpływem współczucia” - art. $150 \mathrm{KK})^{34}$. Znamię ,pod wpływem silnego wzburzenia usprawiedliwionego okolicznościami” z art. 148 § 4 KK to niemal klasyczne określenie warunków zmniejszonej winy w ujęciu teorii normatywnej winy! Nie chodzi w tym przypadku o subiektywne znamiona bezprawia (bezprawności), które charakteryzują funkcję realizacyjną woli sprawcy i jednocześnie pośrednio wpływają na zawinienie (podwójna funkcja, np. „cel przywłaszczenia” w art. 278 § $1 \mathrm{KK}$, „cel osiągnięcia korzyści majątkowej” w art. $286 \S 1 \mathrm{KK}$ ), lecz o znamiona, które określają bliżej sam proces tworzenia woli sprawcy ${ }^{35}$. Bliska mi jest koncepcja tzw. podwójnego usytuowania zamiaru, której podstawy wypracowywano m.in. przy okazji rozważań nad problematyką urojenia znamienia kontratypu. Na użytek die rechtsfolgenverweisende Schuldtheorie przyjęto bowiem, że zamiar w obszarze bezprawia jest nośnikiem finalności i przez to oczywiście ujemności czynu, natomiast w obszarze winy wyraża typową ujemność nastawienia sprawcy naruszenia prawa ${ }^{36}$. Wprawdzie koncepcja ta stworzona została $\mathrm{w}$ określonym otoczeniu normatywnym niemieckiego

34 Zob. Z. Jędrzejewski, Struktura przestępstwa. §5 Bezprawność..., s. 362-363, 368 i n.; idem, Artykut $28 \oint 1$ KK, s. 35-36.

35 Zob. H.-H. Jescheck, Th. Weigend, Lehrbuch des Strafrecht. Allgemeiner Teil, Berlin 1996, s. 318-319, 469 i n.

36 Zob. np. H.H. Jescheck, Th. Weigend, Lehrbuch..., s. 243. Na ten temat szerzej zob. Z. Jędrzejewski, Bezprawność..., s. 541 i n.; idem, Struktura przestępstwa. §5 Bezprawność..., s. 369. 
StGB (karalność form udziału jedynie do czynu umyślnego sprawcy głównego), jednak nie można przekreślać teoretycznej wartości jej założenia. Urojony kontratyp nie wyłącza tu całkowicie Handlungsunrecht (czyn stanowi bezprawie umyślne), odpada raczej wina umyślności (Vorsatzschuld) i w związku z tym wyłączona zostaje jedynie karalność za przestępstwo umyślne (z winy umyślnej) ${ }^{37}$. Ujęcie to koreluje najwyraźniej z rozpowszechnioną w doktrynie niemieckiej interpretacją okoliczności znoszących zawinienie, określanych - w przeciwieństwie do Schuldausschließungsgründe, które znoszą winę całkowicie (niepoczytalność, nieletniość, niemożliwa do uniknięcia nieświadomość bezprawności czynu) - nazwą Entschuldigungsgründe ${ }^{38}$. W przypadku Entschuldigungsgrund (np. tzw. znoszący zawinienie stan konieczności - $\$ 35 \mathrm{StGB}^{39}$ ) zmniejszeniu ulega bezprawie umyślne czynu oraz jednocześnie dwukrotnie wina sprawcy (raz pośrednio w wyniku zmniejszonego bezprawia, drugi raz niezależnie od bezprawia ze względu na anormalną sytuację motywacyjną). W takich sytuacjach zmniejszenie ujemności czynu następuje zarówno w obszarze winy, jak i bezprawia tak, że ostateczna ocena ujemności nie daje podstaw do uznania czynu za czyn przestępny. W ujęciu rechtsfolgenverweisende Schuldtheorie, w sytuacji urojonego kontratypu również następuje redukcja bezprawia umyślnego oraz podwójna redukcja winy z tym rezultatem, że wyłączona zostaje jedynie wina umyślności, otwiera się natomiast droga do odpowiedzialności w ramach zagrożenia za przestępstwo z winy niemyślnej (czyn w sferze bezprawia pozostaje czynem umyślnym). Bliższa mi jest jednak koncepcja całkowitego wyłączenia bezprawia umyślnego: w wyniku urojenia znamienia kontratypu sprawca chce obiektywnie czegoś zgodnego z prawem (wyłączenie bezprawia umyślnego eliminuje problem winy umyślnej). Nietrafne jest natomiast stanowisko zwolenników Schuldtheorie, że urojenie znamienia kontratypu pociąga zawsze za sobą urojenie sprawcy, że jego czyn jest czynem legalnym ${ }^{40}$.

37 Szerzej H.H. Jescheck, Th. Weigend, Lehrbuch..., s. 464-465.

38 Zob. Z. Jędrzejewski, Bezprawność..., s. 485, 546.

39 Podobnie traktuje się regulację § 33 StGB. Odpowiednikiem tego przepisu w polskim KK jest art. $25 \S 3$. Przekroczenie granic obrony koniecznej oznacza zmniejszone bezprawie czynu, idzie za tym obniżony stopień winy, poza tym podjęcie czynu pod wpływem strachu lub wzburzenia usprawiedliwionych okolicznościami zamachu oznacza drugie, niezależne od bezprawia zmniejszenie winy.

40 Na przykład sprawca uroił sobie zamach na jego życie ze strony niepoczytalnego i jednocześnie sądzi, że obrona konieczna w przypadku zachowania niepoczytalnych nie jest przez prawo dozwolona. Jest to tzw. błąd podwójny zorientowany na bezprawność czynu. Zob. F. Haft, Der doppelte Irrtum im Strafrecht, „Juristische Schulung” 1980, s. 431-432. Na ten temat Z. Jędrzejewski, Bezprawność..., s. 557 i n., 560 i n. 
Przedmiotem analizy z punktu widzenia podwójnego usytuowania czy też mieszanego charakteru umyślności (zamiaru) i nieumyślności należy uczynić konkretne ich formy. Moim zdaniem, odpowiednikiem welzlowskiej finalności w sensie woli kreującej, urzeczywistniającej znamiona typu (bezprawie), może być jedynie zamiar bezpośredni. Umyślność $\mathrm{w}$ formie zamiaru bezpośredniego jest $\mathrm{z}$ jednej strony czynnikiem sterującym ludzkim zachowaniem $\mathrm{w}$ kierunku naruszenia dobra (jest więc nośnikiem bezprawia umyślnego; tzw. ujemność czynu, Handlungsunwert), jednocześnie efektem końcowym należącego do winy procesu tworzenia się woli popełnienia czynu zabronionego ${ }^{41}$. Rozdzielenie jego funkcji w obszarze bezprawia i winy jest dosyć trudne. Poza przykładem podawanym przez zwolenników rechtsfolgenverweisende Schuldtheorie (wyłączenie jedynie winy umyślnej), co do którego mam wątpliwości (opowiadam się raczej za pełnym wyłączeniem ujemności umyślnego bezprawia), bardziej obrazowo pokazać to mogą sytuacje, w których „umyślność” nie ma charakteru faktora urzeczywistniającego czyn zabroniony (brak bezprawia umyślnego) mimo istnienia potencjalnie „ujemnie” ocenianej sytuacji motywacyjnej, np. czyn nieudolny określany w nauce niemieckiej jako abergläubischer Versuch czy za KK z 1932 roku jako usiłowanie ,z zabobonu lub ciemnoty” lub tzw. przypadek bogatego wujka - Erbonkelfall (brak możliwości obiektywnego przypisania skutku, mimo istnienia „złego nastawienia” sprawcy, a precyzyjniej - mimo istnienia ujemnie ocenianej sytuacji motywacyjnej). Brak tu elementu bezprawia, a więc przypisanie winy nie jest możliwe ${ }^{42}$.

$\mathrm{W}$ jednej z moich publikacji przyjąłem również kompleksowy, mieszany charakter tzw. zamiaru ewentualnego ${ }^{43}$. W aspekcie funkcji urzeczywistniającej woli (bezprawia) tzw. zamiarowi ewentualnemu bliżej do „kauzalności” niż do „finalności”. Finalność odpowiada jedynie zamiarowi bezpośredniemu. Nie obejmuje ona również świadomej nieumyślności, tak jak to teleologicznie (na podstawie funkcji motywacyjnej normy) zakłada np. H.-H. Jescheck ${ }^{44}$. Moim zdaniem,

41 H.-H. Jescheck, Th. Weigend, Lehrbuch..., s. 242 i n.

42 Zob. również Z. Jędrzejewski, Artykut $28 \S 1$ KK..., s. 36; idem, Struktura przestepstwa. $\$ 5$ Bezprawność..., s. 369-370.

43 Z. Jędrzejewski, Usytuowanie zamiaru ewentualnego w strukturze przestępstwa, w: Węzłowe problemy prawa karnego, kryminologii i polityki kryminalnej. Księga pamiatkowa ofiarowana Profesorowi Andrzejowi Markowi, red. V. Konarska-Wrzosek, J. Lachowski, J. Wójcikiewicz, Warszawa 2010, s. 117 i n.; idem, Struktura przestęstwa. §5 Bezprawność..., s. 370.

44 Zob. H.-H. Jescheck, Aufbau und Stellung des bedingten Vorsatzes im Verbrechensbegriff, w: Existenz und Ordnung. Festschrift für Erik Wolf zum 60. Geburtstag, Frankfurt am Main 1962, s. 473 i n. 
przypadki czynu zabronionego popełnionego z tzw. zamiarem ewentualnym oraz z lekkomyślności w obszarze bezprawia nie różnią się jakościowo: sprawca ma świadomość przekraczania reguł ostrożności (granic dozwolonego ryzyka) oraz świadomość możliwości realizacji znamion czynu zabronionego (jakościowo inaczej zamiar bezpośredni - finalność). Różnice występują w obszarze winy: w przypadku lekkomyślności sprawca „,bezpodstawnie przypuszcza, że uniknie realizacji znamion czynu zabronionego", w przypadku zamiaru ewentualnego sprawca godzi się z możliwością realizacji znamion. „Godzenie się” jest elementem procesu motywacyjnego towarzyszącego tworzeniu się decyzji podjęcia czynu (winy). $Z$ powodu braku jakościowych różnic na płaszczyźnie bezprawia skłonny byłbym przyjąć, że w obydwu wypadkach sprawca przekracza tę samą normę sankcjonowaną ${ }^{45}$. W każdym razie „bezpodstawne przypuszczenie” sprawcy, że skutku uniknie, oraz „godzenie się”, będąc elementami winy, nie stanowią znamion konstytutywnych przekroczenia normy sankcjonowanej (bezprawności). O ile więc według zwolenników koncepcji „obiektywnej” bezprawności (np. akceptujący definicję przestępstwa A. Zolla) czyny umyślne i odpowiadające im czyny nieumyślne (np. art. $148 \S 1$ i art. $155 \mathrm{KK}$ ) przekraczają tę samą normę, a finaliści przyjmują tu przekroczenie dwóch różnych norm (zamiar oraz naruszenie obiektywnego obowiązku staranności są elementami zakresów różnych norm), skłaniam się raczej do koncepcji przekroczenia trzech norm (z zamiarem bezpośrednim; ze świadomością możliwości realizacji znamion czynu, co odpowiada formom zamiaru ewentualnego i lekkomyślności; bez świadomości możliwości realizacji znamion w wypadku niedbalstwa).

We współczesnej nauce niemieckiej od dawna przeważa pogląd o mieszanym charakterze nieumyślności czynu, w tym nieumyślności nieświadomej. Nieumyślność przypisywana jest zarówno do kategorii bezprawia (bezprawności), jak i winy ${ }^{46}$. Na płaszczyźnie bezprawności lokowane jest m.in. przekroczenie obiektywno-generalnej reguły ostrożności (staranności) oraz obiektywno-generalna przewidywalność popełnienia czynu zabronionego. Są to konstytutywne elementy przekroczenia normy sankcjonowanej. Natomiast konkretno-indywidualna możliwość sprawcy wypełnienia obowiązku ostrożności oraz konkretno-indywidualna możliwość przewidzenia przez niego skutku nie są elementami charakteryzującymi

45 Zob. Z. Jędrzejewski, Struktura przestępstwa. \$5 Bezprawność..., s. 370.

46 Zob. H.-H. Jescheck, Th. Weigend, Lehrbuch..., s. 563 i n.; zob. również H.-H. Jescheck, Rozwój i obecny stan nauki o winie nieumyślnej w Republice Federalnej Niemiec $i$ w Polsce, „Palestra" 1979, nr 11-12, s. 71 i n. Zob. Z. Jędrzejewski, Struktura przestępstwa. §5 Bezprawność, s. 370; idem, Artykut 28\$1 KK..., s. 36-37. 
bezprawie czynu, stanowią elementy zawinienia i powinny być pozytywnie ustalane i udowadniane (art. 9 § 2 polskiego KK z 1997 r.). Dlatego krytycznie należy ocenić rezygnację z kompleksowych konstrukcji lekkomyślności i niedbalstwa oraz wspomnianą wyżej nowelizację art. $28 \S 1 \mathrm{KK}$. W ten sposób wprowadzono domniemanie winy (nieumyślnej) oparte na bezprawności czynu. Natomiast, moim zdaniem, swego rodzaju domniemanie winy umyślnej wynika z wartościującego charakteru umyślności (funkcja w obszarze winy) ${ }^{47}$.

Przechodząc do problematyki znowelizowanego art. $28 \S 1$, warto przypomnieć założenia metodologiczne autorów kodyfikacji karnej z 1997 roku odnośnie do elementów struktury przestępstwa, w szczególności strony podmiotowej i winy. W uzasadnieniu do projektu KK z 1995 roku możemy więc przeczytać, że „kierując się wskazaniami współczesnej doktryny prawa karnego, projekt wyraźnie oddziela winę od podmiotowej strony czynu zabronionego (umyślności albo nieumyślności)”, ,pominięte pozostaje (...) w projekcie rozróżnienie między lekkomyślnością a niedbalstwem”, bowiem „pojęcia »lekkomyślność« i »niedbalstwo « zawierają (...) mieszaną strukturę zacierającą różnicę pomiędzy winą a stroną podmiotową"48. Podobnie już w 1990 roku A. Zoll przedstawiał założenia wcześniejszego projektu kodeksu karnego ${ }^{49}$. Jego zdaniem, lekkomyślność i niedbalstwo są pojęciami, które właśnie ujawniają pomieszanie elementów dotyczących strony podmiotowej czynu zabronionego z elementami wartościującymi, przesądzającymi zarzucalność popełnionego czynu.

Nie jest istotne, czy A. Zoll przyjął metodologiczny kanon ontologizującego finalizmu H. Welzla (poza funkcją zamiaru w bezprawiu), czy też kierował się wskazaniami metodologicznymi neokantyzmu z drugiej czy trzeciej dekady XX wieku. Można tylko stwierdzić daleko idącą zbieżność stanowiska tego autora z rezultatami powojennego welzlowskiego finalizmu. Arbitralnie przyjęte założenie o konieczności ścisłego rozdziału przedmiotu oceny (znamiona typu) od samej oceny (bezprawność, wina) przyniosło jednak negatywne skutki w postaci naruszenia zasady winy.

Konsekwentna denormatywizacja pojęcia nieumyślności (dawnej „lekkomyślność”, „niedbalstwo”) doprowadziła w nauce polskiej do konstatacji, że

47 Zob. Z. Jędrzejewski, Artykut $28 \$ 1$ KK..., s. 35 i n.; idem, Struktura przestęstwa. 55 Bezprawność..., s. 370-371.

48 Projekt KK, sierpień 1995 (art. 29), Druk (sejmowy) nr 1274, Uzasadnienie, s. 3, 5. Zob. Z. Jędrzejewski, Strona podmiotowa..., s. 147-148.

49 A. Zoll, Ogólne zasady odpowiedzialności karnej, „Państwo i Prawo” 1990, nr 10, s. 33-34. 
„nieumyślność” jest jedynie prostym zaprzeczeniem umyślności ${ }^{50}$. Łatwo więc można zgodzić się ze stwierdzeniem np. P. Kardasa, że negatywne ujęcie klauzuli winy $\mathrm{w}$ art. $1 \S 3$ połączone $\mathrm{z}$ katalogiem okoliczności wyłączających winę przesądza o istnieniu w polskim KK domniemania winy ${ }^{51}$, natomiast nie da się, moim zdaniem, takiego rezultatu zaakceptowaćs2 ${ }^{52}$. Odejście od podstawowych zasad prawa karnego (zasady winy) i jego funkcji gwarancyjnej w takim zakresie nie może być usprawiedliwione. Zakłada się bowiem istnienie winy (nieumyślnej) na podstawie li tylko realizacji przedmiotowych znamion typu. Zmiana brzmienia art. $28 \S 1 \mathrm{KK}$ jest logiczną konsekwencją przyjętego założenia o ostrej separacji przedmiotu oceny od samej oceny. Przyjmuje się przy tym obiektywno-generalną wykładnię zwrotu „mógł przewidzieć” z art. 9 § $2 \mathrm{KK}$ (tzw. obiektywna przewidywalność - znamię przedmiotowe ${ }^{53}$ ). Konkretno-indywidualnej możliwości przewidzenia udowadniać już nie trzeba. Dziwnie mogłaby w tym kontekście zabrzmieć teza, że oczyszczona ze wszystkich elementów normatywnych nieumyślność nieświadoma posiada swoją stronę podmiotową (brak umyślności?). W tym nowym ujęciu kryteria, czy błąd co do okoliczności stanowiącej znamię typu był ,usprawiedliwiony”, powinny - tak jak w art. 29 i $30 \mathrm{KK}$, a w przeciwieństwie do art. $9 \S 2 \mathrm{KK}$ - prowadzić do oceny subiektywno-konkretnej.

Stanowisko o radykalnej denormatywizacji istoty czynu (Tatbestand), w tym jej strony podmiotowej, i przeniesieniu wszelkich ocen na płaszczyzny bezprawności i winy, we współczesnej nauce niemieckiej nie jest już praktycznie reprezentowane. Denormatywizacja umyślności, tak jak ujmował to w pewnym okresie H. Welzel, oznacza radykalną separację umyślności (zamiaru) od jakiegokolwiek wartościowania (finalność jest ontologiczną „stałą” systematyki

50 Tak np. J. Majewski, Nieumyślność a brak umyślności, w: Nieumyślność. Pokłosie VIII Bielańskiego Kolokwium Karnistycznego, red. J. Majewski, Torun 2012, s. 35 i n.; W. Wróbel, Wina $i$ zawinienie a strona podmiotowa czynu zabronionego, czyli o potrzebie postugiwania się w prawie karnym pojęciem winy umyślnej i winy nieumyślnej, w: Przestępstwo - kara - polityka kryminalna. Problemy tworzenia i funkcjonowania prawa. Ksiega jubileuszowa z okazji 70. rocznicy urodzin Profesora Tomasza Kaczmarka, red. J. Giezek, Kraków 2006, s. 665.

51 P. Kardas, Problem usprawiedliwienia błędu a podstawy wyłaczenia winy, w: Okoliczności wyłączające winę. Materiały VI Bielańskiego Kolokwium Karnistycznego, red. J. Majewski, Torun 2010, s. 102.

$52 \mathrm{Na}$ ten temat zob. Z. Jędrzejewski, Artykut $28 \S 1$ KK..., s. 33 i n.

53 Chodzi tu o jedno z kryteriów ustalania tzw. obiektywnego przypisania realizacji przedmiotowych znamion (skutku), ponieważ autorzy krakowscy głoszą, moim zdaniem, sporną tezę, że wszystkie te kryteria stosuje się nie tylko przy nieumyślnych, ale również i umyślnych czynach zabronionych. Konieczność obiektywnego przypisania nie stanowi tu szczególnej charakterystyki typu nieumyślnego. 
przestępstwa”). Umyślność jest postrzegana naturalistycznie jako „wola urzeczywistniająca przebiegi kauzalne”. Stąd np. w sytuacji nieświadomości bezprawności czynu finaliści odrzucają konsekwentnie tzw. teorię zamiaru, natomiast przyjmują tzw. teorię winy, rozwiązując przy jej pomocy nawet przypadek urojenia okoliczności stanowiącej znamię kontratypu. Na rodzimym gruncie charakterystyczna jest wypowiedź np. A. Zolla, przeciwnika teorii negatywnych znamion oraz zwolennika Schuldtheorie, który uznał za trafne tezy wyroku SN z 7 kwietnia 1977 roku (jeszcze na gruncie KK z 1969 r.), że „zamiar zarówno bezpośredni, jak i ewentualny oznacza zjawisko obiektywnej rzeczywistości, realny przebieg procesów psychicznych, nie jest zaś pojęciem z dziedziny ocen czy też z dziedziny wartości” ${ }^{54}$. Akceptując ogólne tezy A. Zolla, trzeba więc oczyścić ze wszelkich elementów ocennych także znamiona „strony podmiotowej” nieumyślności. Z obszaru świadomej nieumyślności usuwa się „bezpodstawność” przewidywania sprawcy, że uniknie realizacji znamion czynu zabronionego, a z zakresu nieświadomej nieumyślności (dawniej niedbalstwo) możliwość przewidzenia możliwości realizacji znamion przedmiotowych czynu zabronionego. Pozostaje już tylko w jakiś sposób zniwelować „niepokojącą” zwolenników tego stanowiska różnicę w psychologicznym ujęciu świadomej i nieświadomej nieumyślności. Jak już o tym wspomniano, niektórzy dochodzą do wniosku, że nieumyślność jako strona podmiotowa to po prostu „brak zamiaru”.

Nowe brzmienie art. $28 \S 1 \mathrm{KK}$ wraz z określonym otoczeniem normatywnym i jego wykładnią (negatywne sformułowania art. $1 \S 3$ i 28 § 1, obiektywistyczna interpretacja art. $9 \S 2 \mathrm{KK}$ ) prowadzi do niedającego się zaakceptować na gruncie prawa karnego demokratycznego państwa prawnego rezultatu: przyjęcia domniemania winy (nieumyślnej) na podstawie realizacji li tylko znamion przedmiotowych czynu zabronionego (nieumyślność jako jedynie negacja umyślności) ${ }^{55}$. Jest to następstwo stosowania formalno-logicznej metodologii systemowej zwolenników ostrej separacji ,podmiotowych" znamion typu od winy.

Potrzeba pozytywnego ustalania możliwości przewidzenia sprawcy na podstawie konkretno-indywidualnie (subiektywnie) interpretowanej przesłanki art. 9 § 2 KK („,mógł przewidzieć”) wynika z braku wskaźnikowej funkcji nieświadomej nieumyślności, realizacja znamion takiego typu nie niesie ze sobą ujemnie ocenianej decyzji sprawcy. Wprowadzenie elementów normatywnych

54 Zob. A. Zoll, Kodeks Karny. Cześć ogólna. Komentarz, t. I, Warszawa 2007, s. 109-119. Na ten temat Z. Jędrzejewski, Artykut $28 \$ 1$ KK..., s. 31.

55 Z. Jędrzejewski, Artykut 28\$1 KK..., s. 34-35. 
do określenia wymaganego warunku nieumyślności czynu (niedbalstwa, winy nieumyślnej) jest więc konieczne ze względu na gwarancyjny charakter zasady winy. W takim wypadku art. $28 \S 1 \mathrm{KK}$ w nowym brzmieniu jest tak samo zbędny, jak zbędny był w brzmieniu poprzednim w kontekście art. $9 \S 1 \mathrm{KK}^{56}$. Zawarty w art. $9 \S 2 \mathrm{KK}$ zwrot „mógł przewidzieć” musi być interpretowany subiektywistycznie, a istnienie tej pozytywnie ujętej przesłanki udowodnione sprawcy. Jej ustalanie polega również na porównaniu z jakimś wzorcem osobowym, który jednak jak najdalej uwzględnia indywidualne możliwości konkretnego sprawcy, nie może więc stanowić normatywno-generalnego wzorca w postaci możliwości jakiegoś „modelowego obywatela”, tak jak to ujmują zwolennicy obiektywnej wykładni tego przepisu (tzw. obiektywna przewidywalność).

Znamion typu czynu zabronionego nie da się traktować jako wolny od wartościowania zestaw znamion przedmiotowych i podmiotowych. Wszystkie te znamiona, zarówno przedmiotowe, jak i podmiotowe, mogą pełnić w różnych konstelacjach funkcję charakterystyki ujemności czynu w odniesieniu do dobra prawnego (jego zagrożenia lub naruszenia) i jednocześnie współokreślać proces decyzyjny (oddziaływanie pośrednie) albo charakteryzować wyłącznie sam proces tworzenia się woli. Całkowicie nietrafne jest stanowisko, że umyślność ma charakter wyłącznie deskryptywny (jest wolna od wartościowania). Umyślność jest ujemnie wartościowana poprzez świadomość (rozpoznawalność) ujemnej antyspołecznej wartości poszczególnych znamion i ich całego zestawu typizującego czyn, w szczególności znamion normatywnych (ocennych) ${ }^{57}$. Psychiczne momenty umyślności stanowią „kręgosłup” zarzutu winy, mają więc podstawową wagę dla jej przypisania. Nie ulega wątpliwości, że kryteria zawinienia niekiedy ulegają pewnemu „poluzowaniu”, wynikającym często ze względów czysto praktycznych (np. regulacja błędu co do bezprawności), pamiętać jednak trzeba, że istnieją tu pewne nieprzekraczalne granice. Przyjęcie domniemania winy (nieumyślnej) na podstawie realizacji jedynie znamion przedmiotowych czynu zabronionego nie wchodzi w ogóle w rachubę. Jak się wydaje, można jednak przyjąć, że wartościująco rozumiana umyślność spełnia funkcję wskazywania (domniemywania) na istnienie typowego zawinienia czynu zabronionego (tylko do pewnego stopnia dotyczy to również świadomej nieumyślności). Z powodu braku elementu psychicznego funkcji takiej nie da się natomiast przypisać nieświadomej nieumyślności. Tak więc muszą tu istnieć dodatkowe, szczególne

56 Ibidem, s. 35.

57 Ibidem, s. 37. 
przesłanki pozytywnego ustalania winy (nieumyślnej) sprawcy. W przypadku nieświadomej nieumyślności przesłankę tę stanowi m.in. ustalenie, że konkretno-indywidualnie sprawca mógł przewidzieć realizację przedmiotowych znamion typu czynu zabronionego ${ }^{58}$, w przypadku nieumyślności świadomej „bezpodstawność” przypuszczenia, że znamiona czynu nie zostaną zrealizowane. Cały „opis” czynu zabronionego nie jest wolny od ocen. Zawarta jest w nim zarówno typizacja bezprawia czynu, jak i musi on charakteryzować typowo istniejące zawinienie. W tym sensie realizacja przez sprawcę znamion typu wskazuje na bezprawność czynu, jak i niesie ze sobą typową ocenę procesu decyzyjnego sprawcy (wina) ${ }^{59}$. W wypadku, gdy istota czynu takiej funkcji wskaźnikowej z jakichś powodów nie pełni, konieczny jest dodatkowy pozytywnie ustalany element bezprawności (np. znamię „wbrew przepisom”) bądź winy (tak „możliwość przewidzenia” przy nieświadomej nieumyślności). Oceny te mogą zostać „wyłączone”, jeżeli istniały odpowiednio: sytuacje kontratypowe odnośnie do oceny bezprawności czynu, czy tzw. okoliczności znoszące zawinienie odnośnie do winy.

\section{Literatura}

Haft F., Der doppelte Irrtum im Strafrecht, ,Juristische Schulung” 1980.

Jescheck H.-H., Aufbau und Stellung des bedingten Vorsatzes im Verbrechensbegriff, w: Existenz und Ordnung. Festschrift für Erik Wolf zum 60. Geburtstag, Frankfurt am Main 1962.

Jescheck H.-H, Rozwój i obecny stan nauki o winie nieumyślnej w Republice Federalnej Niemiec i $w$ Polsce, ,Palestra” 1979, nr 11-12.

Jescheck H.-H., Weigend Th., Lehrbuch des Strafrecht. Allgemeiner Teil, Berlin 1996.

Jędrzejewski Z., Bezprawność jako element przestępności czynu. Studium na temat struktury przestępstwa, Warszawa 2009.

Jędrzejewski Z., Usytuowanie zamiaru ewentualnego w strukturze przestępstwa, w: Węzłowe problemy prawa karnego, kryminologii i polityki kryminalnej. Ksiega pamiatkowa ofiarowana Profesorowi Andrzejowi Markowi, red. V. Konarska-Wrzosek, J. Lachowski, J. Wójcikiewicz, Warszawa 2010.

Jędrzejewski Z., Artykut $28 \$ 1$ KK po nowelizacji z dnia 20 lutego 2015 r. Uwagi na temat konieczności oddzielania strony podmiotowej czynu zabronionego od winy, „Studia Iuridica” 2016, t. 65.

58 Zob. H.-H. Jescheck, Th. Weigend, Lehrbuch..., s. 430.

59 Zob. Z. Jędrzejewski, Artykut 28\$1 KK..., s. 35-36. 
Jędrzejewski Z., Strona podmiotowa $i$ wina, przedmiot oceny i ocena a tzw. ścisła teoria winy, w: Prawo wobec problemów społecznych. Księga Jubileuszowa Profesor Eleonory Zielińskiej, red. B. Namysłowska-Gabrysiak, K. Syroka-Marczewska, A. Walczak-Żochowska, Warszawa 2016.

Jędrzejewski Z., Okoliczności wyłaczające bezprawność. Zagadnienia ogólne, w: System Prawa Karnego, t. 4 Nauka o przestęstwie. Wyłaczenie i ograniczenie odpowiedzialności karnej, wyd. II, red. L. Paprzycki, Warszawa 2016.

Jędrzejewski Z., Struktura przestępstwa. §5 Bezprawność, w: System Prawa Karnego, t. 3, Nauka o przestępstwie. Zasady odpowiedzialności, wyd. II, red. R. Dębski, Warszawa 2017.

Kardas P., Problem usprawiedliwienia błędu a podstawy wyłaczenia winy, w: Okoliczności wyłączające winę. Materiały VI Bielańskiego Kolokwium Karnistycznego, red. J. Majewski, Toruń 2010.

Kunert K.H., Die normativen Merkmale der strafrechtlichen Tatbestände, Berlin 1958.

Majewski J., Nieumyślność a brak umyślności, w: Nieumyślność. Pokłosie VIII Bielańskiego Kolokwium Karnistycznego, red. J. Majewski, Toruń 2012.

Roxin C., Offene Tatbestände und Rechtspflichtmerkmale, Hamburg 1959.

Roxin C., Zur Kritik der finalen Handlungslehre, „Zeitschrift für die gesamte Strafrechtswissenschaft" 1962, Bd. 74.

Schaffstein F., Soziale Adäquanz und Tatbestandslehre, „Zeitschrift für die gesamte Strafrechtswissenschaft" 1960, Bd.72.

Welzel H., Studien zum System des Strafrechts, „Zeitschrift für die gesamte Strafrechtswissenschaft" 1938, Bd. 58.

Welzel H., Aktuelle Strafrechtsprobleme im Rahmen der finalen Handlunglehre, Karlsruhe 1953.

Welzel H., Das Deutsche Strafrecht. Eine systematische Darstellung, 11 Aufl. Berlin 1969.

Wróbel W., Wina i zawinienie a strona podmiotowa czynu zabronionego, czyli o potrzebie postugiwania się w prawie karnym pojęciem winy umyślnej $i$ winy nieumyślnej, w: Przestęstwo - kara - polityka kryminalna. Problemy tworzenia i funkcjonowania prawa. Ksiega jubileuszowa z okazji 70. rocznicy urodzin Profesora Tomasza Kaczmarka, red. J. Giezek, Kraków 2006.

Zoll A., Okoliczności wyłączające bezprawność czynu, Warszawa 1982.

Zoll A., Ogólne zasady odpowiedzialności karnej, „Państwo i Prawo” 1990, nr 10. 


\title{
THE SOCIETAL-EVALUATIVE (NORMATIVE) AND THE DESCRIPTIVE CHARACTER OF THE MENS REA OF A CRIMINAL OFFENCE. A COM- PREHENSIVE AGAINST A (PURELY) NORMATIVE ACCOUNT OF FAULT (THE EXAMPLE OF THE REGULATION OF ERROR AS TO THE EXIST- ENCE OF A CIRCUMSTANCE EXCLUDING UNLAWFULNESS AND ARTI- CLE 28 § 1 OF THE CRIMINAL CODE AS AMENDED)
}

\begin{abstract}
Summary
The paper tackles the mutual relation between the essence of a criminal offence (Tatbestand in German) and other elements comprising the structure of a criminal act, i.e. illegality and fault, a matter contentious in the study of criminal law. Special attention is devoted to discussing the character of the relation between the mens rea of an offence and fault. This is related to a postulate often put forward by Polish academic commentators that it is necessary to radically separate these two notions. This view is reflected in the provisions of the 1997 Polish Criminal Code. In line with such an argument are regulations whose subject is error as to the existence of a circumstance excluding illegality (Article 29) and error as to an element of an offence (Article $28 \S 1$ as amended on 20 February 2015). Underpinning these regulations is the assumption that the elements of mens rea (intention and non-intention) belong to the elements of an offence, however they have no constitutive significance both as regards establishment of illegality of an act as well as the offender's fault. Intention and non-intention are sharply separated from fault (perceived "purely normatively"). According to this account the totality of elements of a prohibited act (the essence of an act) is of a descriptive character and remains free from any evaluation. The view has been endorsed by H. Welzel, the founder of "finalism" in the German literature, and A. Zoll in Poland. The paper attempts an analysis of the view of $\mathrm{H}$. Welzel following his "ontological swerve" in the 1960s. Denormativization of, inert alia, the concept of intention as an element of an offence, separation thereof from any evaluative context, has led finalists to adopting the so-called strict theory of fault (die strenge Schuldtheorie). The situation is similar as regards the systematics of offences accepted by representatives of the Cracow school of thought (A. Zoll). Error as to the existence of a circumstance excluding unlawfulness does not exclude the illegality of an intentional act and this shall be resolved exclusively by reference to fault (Article 29 of the Polish Criminal Code). Also, the new wording of Article $28 \S 1$ is a manifestation of the view that mens rea elements of an offence shall be subject to denormativization.
\end{abstract}


The author argues contrary in the paper, contending in favour of a societal-evaluative (normative) account of the essence of an act and intention (intent). This means that, when the object of intention (the offender's consciousness) is ascertained, of significance are or may be not only "factual circumstances" forming the foundation of the elements of an offence, but also their societal (normative) context and meaning, awareness of social harmfulness), or even, potentially, the legal assessment of an act. To overlook this entire context (intention perceived "naturalistically") leads to the so-called strict theory of fault. The author maintains that the concept mandating total exclusion of intentional illegality is correct: in cases of error as to the existence of a circumstance excluding unlawfulness the offender objectively wants something legal. At the same time, intention must (also) finds its place alongside fault (comprehensive, psychological-normative theory of fault). Actualization of the elements of an offence triggers a negative assessment both in the realm of illegality and that of fault. For in both realms it performs a "directional" function, therefore the typification of a criminal act shall already encompass elements of fault. The paper argues that direct intention shall be located both within illegality and fault. A comprehensive, hybrid character may also be proven as regards so-called dolus eventualis and non-intention. This is why the author furnishes a critique of the views in support of renouncing comprehensive theories of carelessness and negligence and of the aforementioned amendment to Article $28 \S 1$ of the Criminal Code. In his estimation, some form of presumption of intentional fault may result from the evaluative character of intention (its function within the realm of fault). Consistent denormativization of the notion of non-intention (previously known as "carelessness", "negligence") has led Polish academic commentators to the conclusion that the mens rea of "non-intention" is simply "lack of intent". The new wording of Article $28 \S 1$ of the Criminal Code, together with certain normative context and its construction (negative formulations of Articles $1 \S 2$ and $28 \S 1$, the objectivist interpretation of Article $9 \S 2$ ) gives rise to an account unacceptable in the criminal law within a democratic state governed by the rule of law: endorsement of a presumption of non-intentional fault based upon the actualization of the actus reus of a criminal offence. The need to positively establish the possibility of an offender's foresight by reference to a concrete-individual (subjective) interpretation of the requirement of Article $9 \S 2$ of the Criminal Code ("could have foreseen") stems from unconscious non-intention's lack of directional function, and an actualization of the elements of such an offence does not induce a negative assessment of the offender's decision.

Keywords: essence of an act (Tatbestand in German), elements of an offence, illegality, fault, finalism, H. Welzel, error as to an element of a criminal offence, error as to the existence of a circumstance excluding unlawfulness, purely normative theory of fault, so-called intent theory (Vorsatztheorie in German), so-called strict theory of fault (die strenge Schuldtheorie in German), comprehensive, 
psychological-normative theory of fault, theory of negative elements of a criminal offence, finality, dolus eventualis, non-intention, negligence, directional function of actualization of elements of an offence, directional function of actualization of mens rea, Article $28 \S 1$ of the Criminal Code, Article 29 of the Criminal Code 